Soil Science and Agricultural Engineering

http:/www.journals.zu.edu.eg/journalDisplay.aspx?Journalld=1\&queryType=Master

\title{
RESPONSE OF WHEAT PLANTS TO DIFFERENT ORGANIC EXTRACTS UNDER SANDY SOIL CONDITIONS
}

\author{
Amera M. Sabri", I.R. Mohamed, A.E. Nasrallah and A.M.A. Merwad \\ Soil Sci. Dept., Fac. Agric., Zagazig Univ., Egypt
}

Received: 24/06/2019; Accepted: 21/07/2019

\begin{abstract}
A pot experiment was conducted under greenhouse condition at the Experimental Farm, Faculty of Agriculture, Zagazig University, Egypt to investigate spraying with different organic extracts, Moringa leaves extract (MLE); Alge extract (AE); Yeast extract (YE) and Cabbage pollen flowers extract (CPFE) on grains and straw yields, photosynthetic pigments and nutrient uptake of wheat grown on a sandy soil taken from El-Khattara county, Sharkia Governorate, Egypt. Results showed that spraying with different organic extracts significantly increased yield, protein content, photosynthetic pigments and nutrient uptake of $\mathrm{N}, \mathrm{P}, \mathrm{K}, \mathrm{Fe}, \mathrm{Mn}, \mathrm{Zn}$, and $\mathrm{Cu}$ as compared to untreated plants. Spraying with MLE was of most positive effect and caused an increase of all parameters i.e., straw and grain yields, biological yield, protein content, NPK, Fe, $\mathrm{Zn}, \mathrm{Cu}$ an $\mathrm{Mn}$-uptake of wheat plants compared to other extracts.
\end{abstract}

Key words: Moringa leaves, yeast extract, alge extract, wheat, sandy soil.

\section{INTRODUCTION}

Wheat is the most important cereal crop in the world. In Egypt, there is a great gap between consumption and production of wheat (FAO, 2011). Most of the newly reclaimed soils are sandy, which are poor in available nutrients and organic matter (Sharpley, 1985). The increasing use of chemical fertilizers led to using natural substances and natural plant extracts as fertilizers. The use of inorganic fertilizers is associated with high cost and environmental pollution (Phiri and Mbewe, 2010). Organic extracts are useful for many agriculture purpose (Veerappan et al., 2019). There is continuous need to search for safe natural sources of plant nutrients. Moringa oleifera is one of such sources which can be used for growth and yield of crops to substitute inorganic fertilizers (Phiri and Mbewe, 2010). It is a highly nutritive plant as fresh vegetable and livestock fodder. It is used as green manure, biogas, medicine, bio pesticide and seed production (Fuglie, 2000). Elrys and Merwad (2017) showed that spraying with licorice root extract increased fresh pods yield, dry weight of shoots and seeds, protein content and nutrients uptake of pea plants. Moringa leave's extract gave positive results as a plant growth hormone to enhance seed germination, growth and yield of crops (Abusuwar and Abohassan, 2017; AbdelRahman and Abdel-Kader, 2019). Its leaves extract increased crops yields by $25-30 \%$ (Martin, 2008). Prabhu et al. (2009) reported that plant height, leaf area and dry herb weight of Kalmegh were increased with foliar spray of 2\% extract. Merwad (2015) used moringa leaf extract in $4 \%$ ethanol on spinach and obtained an increase in each of yield and NPKaccumulation. The highest value for each of straw, grain yield and nutrient uptake by wheat plants was obtained with 4\% extract of MLE (Merwad and Abdel-Fattah, 2017). The highest value for each of plant height, leaf area, chlorophyll a, b and caroteniods, yield, NPKuptake, 1000 grain weight and protein was obtained with falvic acid combined with moringa leaf extract (Abdel-Fattah and Merwad, 2016). The use of natural seaweed as fertilizer has allowed for partial substitution of conventional synthetic fertilizer (Zhang and Ervin, 2004; Khan et al., 2009). Some

\footnotetext{
*Corresponding author: Tel. : +201019203521

E-mail address: abdo.soil@yahoo.com
} 
commercial seaweed extract products are available for use in agriculture and horticulture and can be used as foliar spray or soil application (Sharma et al., 2015). Algae extracts can be used as bio fertilizers. These extracts are marketed as liquid bio stimulants due to presence of plant growth-promoting substances such as auxins, cytokinins and betaines (Khan et al., 2009). Positive responses include improved germination, root development, leaf quality, general plant vigor, and resistance to pathogens (Wanas, 2002; Khan et al., 2009). Bread yeast Saccharomyces cerevisiae is a bio fertilizer usually added to soil or as foliar spray (Mady, 2009; Hammad and Ali, 2014). It contains substances growth regulators such as gibberellins and auxins (Amer, 2004) and enzymes (AbouAly, 2005). Seaweed extract is rich in nutrients, auxins, gibberellins and cytokinin and helps increasing photosynthesis and improving plant growth (Kulkarni et al., 2019). Veerappan et al. (2019) found that foliar spraying of $3 \%$ horse gram sprout extract or $2 \%$ cow pea sprout extract at tillering and seed filling enhanced yield and nutrient uptake of rice. Desoky et al. (2018) found that foliar spray with bio stimulant increased yield and nutrient uptake of sorghum. Draz et al. (2019) reported that spraying with extracts of henna, acalypha and lantana increased yield, protein content, chlorophyll oxidative enzymes activities and nutrients in wheat plants. Abou El-Magd et al. (2018) showed that spraying with cabbage pollen flowers increased growth and yield of cabbage plants. Mohsen et al. (2016) found that spraying with cyanobacterial extracts increased the plant height, number of leaves/ plant, head weight and yield of lettuce. Mohamed et al. (2019) found that spraying with algae plus moringa leaf extract increased weight of leaves, N, P, K and bulb of garlic plants. Mohamed et al. (2018) found that yield, protein content and NPK uptake of wheat increased by foliar spray of yeast extract. The present work was conducted to study the effect of different organic extracts on growth parameters, yield and nutrient uptake of wheat plants grown on a sandy soil.

\section{MATERIALS AND METHODS}

A pot experiment was conducted under greenhouse condition at the Experimental Farm, Faculty of Agriculture, Zagazig University, Egypt. The experiment aimed to study the effect of organic extracts of moringa leaves, alge, yeast and cabbage pollen flowers on growth and nutrients uptake of wheat (Triticum aestivum L., cv. Sakha 93) grown on a sandy soil.

The soil was taken from the surface layers $(0-30 \mathrm{~cm})$ of a field in El-Khattara County, Sharkia Governorate, Egypt. The soil was air dried for 6 days, crushed, sieved to pass through $2 \mathrm{~mm}$ plastic screen, thoroughly mixed and stored in plastic bags. Main soil properties are given in Table 1. Soil properties were determined according to Piper (1950), Black et al. (1965) and Jackson (1973). Pots capacity was $10 \mathrm{~kg}$. Pots dimentions was $25 \times 30 \mathrm{~cm}$. Three replicates of the two treated soil performed.

Twenty seeds of wheat were seeded per pot. The pots were daily weighed and the soil moisture content was adjusted nearly the field capacity. After germination, plants were thinned to ten plants.

Nitrogen fertilizer was added as ammonium sulphate $\left(205 \mathrm{~g} \mathrm{~N} \mathrm{~kg}^{-1}\right)$ at the rate of $100 \mathrm{mg} \mathrm{N}$ $\mathrm{kg}^{-1}$ soil in three equal splits. The first was 15 days after seeding, the second and third doses were added at tillering ( 45 days after seeding) and booting (75 days after seeding). Before seeding, potassium as potassium sulphate $(400 \mathrm{~g}$ $\mathrm{K} \mathrm{kg}^{-1}$ ) was thoroughly mixed with the soil at a rate of $40 \mathrm{mg} \mathrm{K} \mathrm{kg}^{-1}$. Phosphorus was added as ordinary super phosphate $\left(67.6 \mathrm{~g} \mathrm{P} \mathrm{kg}^{-1}\right)$ at 13 $\mathrm{mg} \mathrm{P} \mathrm{kg}^{-1}$ soil before seeding. Foliar spraying of extracts were done as three equal doses at 30, 45 and 60 days after planting.

\section{Preparation of Organic Extracts}

\section{Preparation of moringa leaves extract}

Twenty grams of young Moringa oleifera leaves was mixed with $675 \mathrm{ml}$ of $80 \%$ ethanol as suggested by Makkar and Becker (1996). The suspension was stirred using a homogenizer then filtered using No.2 whatman filter paper. The extract was used within five hours of extraction. The chemical composition of the extract is in Table 2. Moringa leaves extract used for spraying with dilutes of $30 \mathrm{ml}$ extract $\mathrm{l}^{-1}$ of water $(3 \%)$ in the experiment.

\section{Preparation of yeast extract}

Commercial baking yeast (saccharomyces cerevisiae) was extracted with water adding sugar at ratio1:1 and kept overnight for activation and reproduction of yeast. 
Table 1. Main properties of the soil

\begin{tabular}{|c|c|}
\hline Soil characteristics & Value \\
\hline \multicolumn{2}{|c|}{ Soil particles size distribution } \\
\hline Sand $(\%)$ & 90.5 \\
\hline Silt (\%) & 6.90 \\
\hline Clay $(\%)$ & 2.6 \\
\hline Textural class & Sand \\
\hline Field capacity (FC) (\%) & 9.31 \\
\hline $\mathrm{CaCO}_{3}\left(\mathrm{~g} \mathrm{~kg}^{-1}\right)$ & 4.20 \\
\hline Organic matter $\left(\mathrm{g} \mathrm{kg}^{-1}\right)$ & 3.60 \\
\hline $\mathrm{pH}^{*}$ & 7.89 \\
\hline $\mathrm{EC}\left(\mathrm{dSm}^{-1}\right) * *$ & 0.90 \\
\hline \multicolumn{2}{|c|}{ Soluble cations and anions, $\left(\right.$ mmolc $\left.1^{-1}\right) * *$} \\
\hline $\mathrm{Ca}^{++}$ & 2.85 \\
\hline $\mathrm{Mg}^{++}$ & 2.65 \\
\hline $\mathrm{Na}^{+}$ & 1.55 \\
\hline $\mathrm{K}^{+}$ & 1.95 \\
\hline $\mathrm{CO}_{3}=$ & - \\
\hline $\mathrm{HCO}_{3}^{-}$ & 3.56 \\
\hline $\mathrm{Cl}^{-}$ & 2.98 \\
\hline $\mathrm{SO}_{4}=$ & 2.46 \\
\hline \multicolumn{2}{|c|}{ Available nutrient, (mg kg ${ }^{-1}$ soil ) } \\
\hline $\mathrm{N}$ & 25.9 \\
\hline $\mathrm{P}$ & 5.62 \\
\hline K & 65.7 \\
\hline
\end{tabular}

*Soil-water suspension 1: 1 ** Soil water extract 1:1

Table 2. Chemical composition of moringa oleifera leaves per dry weight (dw)*

\begin{tabular}{lcc}
\hline Component & Value & unit \\
\hline Protein & 273 & \\
Phosphorus (P) & 3.90 & \\
Potassium (K) & 21.70 & $\mathrm{gKg}^{-1} \mathrm{dw}$ \\
Calcium (Ca) & 24.0 & \\
Magnesium (Mg) & 4.5 & \\
Iron (Fe) & 0.582 & \\
Vitamin A (B-carotene) & 163 & \\
Vitamin B1 (thiamine) & 26 & \\
Vitamin B2 (riboflavin) & 210 & \\
Vitamin B3 (nicotinic acid) & 800 & \\
Vitamin C (ascorbic acid) & 1700 & \\
Vitamin E (tochopherol acetate) & 1130 & \\
\hline
\end{tabular}

*According to Fuglie (2000) and Moyo et al. (2011). 
Which allow yeast extract was prepared using a technique yeast cells to grow and multiply, such technique for yeast preparation is after (Morsi et al., 2008). Chemical analysis of yeast extract is presented in Table 3. Yeast extract used for spraying with dilutes of $20 \mathrm{ml}$ extract $\mathrm{L}^{-1}$ of water $(2 \%)$.

\section{Preparation of marine algae extract}

Foliar spray of marine algae extract as Ascophyllum nodosum (Phaeophyceae) at a rate of $1.0 \mathrm{ml} \mathrm{l}^{-1}$. The chemical composition of marine algae extract is shown in Table 4.

\section{Preparation of cabbage pollen flowers}

Extract of cabbage pollen flowers powder was done using water at rate of $10 \mathrm{~g} \mathrm{~L}^{-1}$. The chemical composition of extract is shown in Table 5.

\section{Determinations of Photosynthetic Pigments}

Chlorophylls "a" and "b", as well as carotenoids were extracted by homogenization in pure acetone according to Fadeels (1962) and calculated using the formula of Wettestein (1957). Porline was determined according to Bates et al. (1973).

Plant samples were dried at $70^{\circ} \mathrm{C}$ for $72 \mathrm{hr}$, weighed, ground and analyzed for $\mathrm{N}, \mathrm{P}$ and $\mathrm{K}$ according to Chapman and Pratt (1961). K was measured by flame photometer. Phosphorus was measured colourmetrically using ascorbic acid method (Watanabe and Olsen, 1965).. Protein was calculated by multi plying N\% $\times$ 5.70 (Bishni and Hughes, 1979).

\section{RESULTS AND DISCUSSION}

\section{Growth and Yield Parameters}

Results presented in Table 6 show that all extracts increased plant height, straw, grain and biological weights/plant and 1000-grain weight. The highest growth and yield were obtained with moringa leaf extract. Increase in plant height, straw and grain weight, biological weight, 1000 grain weight and protein content were up to of $69,60,110,80,55$ and $128 \%$, respectively. These results are in agreement with those obtained by Veerappan et al. (2019). Pods and leaves of moringa contains high $\mathrm{Ca}$, $\mathrm{Mg}, \mathrm{K}, \mathrm{Mn}, \mathrm{P}, \mathrm{Zn}, \mathrm{Na}, \mathrm{Cu}$ and $\mathrm{Fe}$ (Merwad,
2015; Parađiković et al., 2019). Moringa leaf extract was suggested as an effective source of nutrition for plants (Abd El-Mageed et al., 2017; Abdel-Rahman and Abdel-Kader, 2019). Since, leaves are rich in nutrients and essential vitamins A, C and E. Draz et al. (2019) reported that foliar spray with organic extracts of henna, chinaberry, pomegranate and lantana extracts increased yield of wheat.

Wheat treated with organic extracts showed increases in grain yield and 1000- grain weight. Increases in grain yield were $110,63,37$ and $20 \%$ caused by MLE, AE, YE and CPFE, respectively. Highest increases in 1000- grain weigh were $55,44,35$ and $23 \%$, respectively. These results are in agreement with those obtained by Abdalla (2013) who found that plant height, fresh and dry weight of rocket plants increased with foliar spray of $2 \%$ moringa leaf extract. Merwad (2018) found that spraying with MLE increased fresh pods yield, shoot and seed yields and 100- seed weight of pea. Merwad and Abdel-Fattah (2017) found that foliar spray with MLE of $4 \%$ caused 77 to $88 \%$ increase in wheat grain yield.

\section{Photosynthetic Pigments and Proline}

Results illustrated in Fig. 1 show that the extracts exhibited high concentration of chlorophyll a, chlorophyll $\mathrm{b}$, carotenoids and proline. Spraying with MLE caused little increases in the photosynthetic pigments but these increases were comparably.

The highest values for each of chlorophyll a, chlorophyll b, carotenoids, and proline was obtained with MLE. The highest percentage increase in each of chlorophyll a, chlorophyll b, carotenoids, and proline were 59, 91, 127 and $98 \%$, respectively. These results are in agreement with those obtained by Abd ElMageed et al. (2017), Bulgari et al. (2019), Parađiković et al. (2019), Mohamed et al. (2018), Mohamed et al. (2019) and Ullah et al. (2019).

Anaysis of MLE indicates that it can be used as a plant biostimulant. It contains nutrients, proline, ascorbic acid, indol-3-acetic acid (IAA), gibberellins (GA) and cytokinin. Percentage increase of $60,39,31$ and $21 \%$ were caused by MLE, AE, YE and CPFE, respectively for pigments and $98,80,74$ and $48 \%$, respectively for 
Zagazig J. Agric. Res., Vol. 46 No. (5) 2019

Table 3. Chemical composition of activated yeast $\left(\mathrm{mg}^{-1} \mathrm{~g}\right.$ dry weight) ${ }^{*}$

\begin{tabular}{lclllc}
\hline Mineral & Value & Amino acid & Value & Vitamin & Value \\
\hline Total $\mathrm{N}$ & 7.23 & Arginine & 1.99 & Thiamin & 2.71 \\
$\mathrm{P}_{2} \mathrm{O}_{5}$ & 51.68 & Histidine & 2.63 & Riboflavin & 4.96 \\
$\mathrm{~K}_{2} \mathrm{O}$ & 34.39 & Isoleiucine & 2.31 & Nicotinic acid & 39.88 \\
$\mathrm{MgO}$ & 5.76 & Leucine & 3.09 & Pantothenic acid & 19.56 \\
$\mathrm{CaO}$ & 3.05 & Lysine & 2.95 & Biotin & 0.09 \\
$\mathrm{SiO}_{2}$ & 1.55 & Methionine & 0.72 & Pyridoxine & 2.90 \\
$\mathrm{SO}_{2}$ & 0.49 & Phrnylalanine & 2.01 & Folic acid & 4.36 \\
$\mathrm{NaCl}_{\mathrm{Fe}}$ & 0.30 & Theronine & 1.09 & Cobalamin & 153 ug- $^{1} \mathrm{~g}$ \\
$\mathrm{Ba}$ & 0.92 & Tryptophan & 0.45 & & \\
$\mathrm{Co}$ & 157.6 & Valine & 2.19 & Oxidase & 0.350 \\
$\mathrm{Mn}$ & 67.8 & Glutamic acid & 2.00 & Peroxidase & 0.290 \\
$\mathrm{Zn}$ & 81.3 & Aspartic acid & 1.33 & Catalase & 0.063 \\
${ }^{*}$ According to Mady (2009) & 335.6 & Proline & 1.53 & Carbohydrates & 23.20 \\
\hline
\end{tabular}

Table 4. The chemical composition (\%) of marine algae extract

\begin{tabular}{|c|c|c|c|c|c|c|c|c|c|c|c|c|}
\hline Characteristic & $\overline{\mathbf{N}}$ & $\overline{\mathbf{P}}$ & $\bar{K}$ & $\overline{C a}$ & $\mathrm{Mg}$ & $\begin{array}{c}\text { Fe, } \\
\text { Ppm }\end{array}$ & $\begin{array}{c}\text { Alginic } \\
\text { acid }\end{array}$ & Cytokinine & $\begin{array}{c}\text { Indol acetic } \\
\text { acid }\end{array}$ & Pepsin & $\begin{array}{c}\text { Oligo } \\
\text { saccharide }\end{array}$ & Phytin \\
\hline$\overline{\text { Value }}$ & 1.33 & 0.46 & 12.40 & 0.55 & 0.35 & 80 & 5.60 & 0.001 & 0.002 & 0.02 & 3.50 & 0.003 \\
\hline
\end{tabular}

Table 5. The chemical composition (\%) of cabbage pollen flowers.

\begin{tabular}{|c|c|c|c|c|c|c|c|c|c|c|c|}
\hline Characteristic & $\bar{N}$ & $\overline{\mathbf{P}}$ & $\bar{K}$ & $\overline{C a}$ & $\mathrm{Mg}$ & $\begin{array}{c}\text { Fe, } \\
\text { Ppm }\end{array}$ & $\begin{array}{c}\text { Alginic } \\
\text { acid }\end{array}$ & Cytokinine & $\begin{array}{c}\text { Indol acetic } \\
\text { acid }\end{array}$ & Pepsin & $\begin{array}{c}\text { Oligo } \\
\text { saccharide }\end{array}$ \\
\hline Value & 1.20 & 0.46 & 12.40 & 0.68 & 0.44 & 90 & 4.7 & 0.002 & 0.003 & 0.04 & 3.2 \\
\hline
\end{tabular}

*According to Abou El-Magd et al. (2018)

Table 6. Effect of organic extracts on plant height and yield of wheat plants grown in sandy soil

\begin{tabular}{lccccccc}
\hline Treatment & $\begin{array}{c}\text { Plant } \\
\text { height } \\
(\mathbf{c m})\end{array}$ & $\begin{array}{c}\text { Straw } \\
\text { weight } \\
\left.\text { (g plant }^{-1}\right)\end{array}$ & $\begin{array}{c}\text { Grain } \\
\text { weight } \\
\left(\mathbf{g ~ p l a n t ~}^{-1}\right)\end{array}$ & $\begin{array}{c}\text { Biological } \\
\text { weight } \\
\left.\text { (g plant }^{-1}\right)\end{array}$ & $\begin{array}{c}\mathbf{1 0 0 0}- \\
\text { grain } \\
\text { weight }(\mathbf{g})\end{array}$ & $\begin{array}{c}\text { Harvest } \\
\text { index } \\
(\mathbf{\%})\end{array}$ & $\begin{array}{c}\text { Protein } \\
\text { content } \\
\left.\mathbf{( g ~ k g}^{-1}\right)\end{array}$ \\
\hline Control & 62.17 & 1.03 & 0.75 & 1.78 & 35.77 & 42.02 & 63.7 \\
MLE & 105 & 1.63 & 1.58 & 3.21 & 55.57 & 49.12 & 144 \\
AE & 95.63 & 1.36 & 1.22 & 2.58 & 51.33 & 47.17 & 134 \\
YE & 88.20 & 1.22 & 1.03 & 2.25 & 48.20 & 45.84 & 115 \\
CPFE & 74.03 & 1.15 & 0.90 & 2.05 & 43.83 & 43.86 & 104 \\
Mean & 85.07 & 1.28 & 1.09 & 2.37 & 46.94 & 45.60 & 112 \\
LSD 0.05\% & 1.6 & 0.21 & 0.18 & 0.12 & 1.02 & 1.1 & 1.4 \\
\hline
\end{tabular}

MLE: Moringa leaves extract; AE: Alge extract; YE: Yeast extract; CPFE: Cabbage pollen flowers extract 
Praline (Table 7). These results are in agreement with those obtained by Desoky et al. (2017) who found that spraying with MLE gave high photosynthetic pigments and proline of pea plants under soil salinity stress. Moringa oleifera ascertains its effect on growth and yield of crops (Abusuwar and Abohassan, 2017; Merwad and Abdel-Fattah, 2017; Thanaa et al., 2017; Bulgari et al., 2019; Ullah et al., 2019). Moringa leaf extract is rich in amino acids, $\mathrm{K}, \mathrm{Ca}$, Fe, ascorbate and growth regulating hormones and is an ideal plant growth enhancer. Different parts of this plant contains important minerals, proteins, vitamins, carotene, amino acids and various phenolics Therefore it is a good source of natural antioxidants (Desoky et al., 2018). Merwad (2019) obtained the highest value for each of plant growth, chlorophyll a, b and caroteniods, NPK-uptake, 1000-grain weight and protein content of wheat with humus materials combined with moringa extract spray under salinity stress.

\section{Macro-Nutrient Uptake}

Results in Table 8 show the effect of foliar spraying with the extracts which increased NPK-uptake. These results are similar to those of Mohamed et al. (2018), Toscano et al. (2019) and Veerappan et al. (2019). The highest values of straw and grain NPK-uptake of wheat was obtained under spraying with MLE. The current results are similar to those of Mohamed et al. (2018) and Parađiković et al. (2019).

The promotive effect of the extracts on NPKuptake may follow the order: MLE $>$ AE $>$ YE $>$ CPFE. The favourable effect of organic extract on nutrient content is mainly due to the positive effect of this material on increasing the growth parameters, photosynthetic pigments and nutrient content (Merwad, 2017; Mohamed et al., 2018; Toscano et al., 2019).

All extracts caused increases in uptake of plant nutrients. Highest increases of 317, 220, 143 and 101\% were given by MLE, AE, YE, CPFE, respectively for $\mathrm{N}$-uptake by straw and $280,153,79$ and $43 \%$, respectively for P-uptake and 306, 179, 125 and 75\%, respectively for Kuptake.

The main actions of extracts are: a) enhance growth of plants, b) contain higher times of nutrients, amino acids, antioxidants, antiaging and anti-inflammatory materials, proteins, vitamins and different minerals (Bulgari et al., 2019; Mohamed et al., 2019; Parađiković et al., 2019).

\section{Micro Nutrient Uptake}

Results of Table 9 show that all extracts gave increases in $\mathrm{Fe}, \mathrm{Zn}, \mathrm{Mn}$ and $\mathrm{Cu}$ uptake. These results agree with that obtained by Selvam and Sivakumar (2014), Merwad (2017), Mohamed et al. (2018) and Bulgari et al. (2019).

The highest uptake for each of Fe, $\mathrm{Zn}, \mathrm{Mn}$ and $\mathrm{Cu}$ was obtained by MLE. The highest percentage increase in $\mathrm{Fe}, \mathrm{Zn}, \mathrm{Mn}$ and $\mathrm{Cu}$ uptake were 197, 222, 192 and 150\%, respectively in straw as well as 267, 313, 270 and 200\%, respectively in grains. These results are in agreement with those obtained by Mohsen et al. (2016) and Parađiković et al. (2019) who found that tomato treated with bio stimulants had greater contents of $\mathrm{N}, \mathrm{P}, \mathrm{K}, \mathrm{Ca}$, and $\mathrm{Mg}$.

Table 7. Effect of organic extracts on Photosynthetic pigments (mg g-1f wt) and proline of wheat plants in sandy soil

\begin{tabular}{ccccc}
\hline Treatment & Chlorophyll a & Chlorophyll b & Carotenoids & Proline $\left(\boldsymbol{\mu g} \mathbf{g}^{-\mathbf{1}} \mathbf{D W}\right)$ \\
\hline Control & 1.02 & 0.45 & 0.33 & 20.73 \\
MLE & 1.63 & 0.86 & 0.75 & 40.98 \\
AE & 1.42 & 0.72 & 0.61 & 37.35 \\
YE & 1.34 & 0.65 & 0.53 & 36.01 \\
CPFE & 1.23 & 0.57 & 0.44 & 30.73 \\
Mean & 1.33 & 0.65 & 0.53 & 33.16 \\
LSD 0.05\% & 0.02 & 0.05 & 0.03 & 0.79 \\
\hline
\end{tabular}

Se footnote of Table 6 . 
Zagazig J. Agric. Res., Vol. 46 No. (5) 2019

Table 8. Effect of organic extracts on $N, P$ and K-uptake (mg plant $\left.{ }^{-1}\right)$ of wheat plants grown in sandy soil

\begin{tabular}{|c|c|c|c|c|c|c|}
\hline \multirow[t]{2}{*}{ Treatment } & \multicolumn{3}{|c|}{ Straw } & \multicolumn{3}{|c|}{ Grains } \\
\hline & $\overline{\mathbf{N}}$ & $\overline{\mathbf{P}}$ & $\bar{K}$ & $\mathbf{N}$ & $\overline{\mathbf{P}}$ & $\bar{K}$ \\
\hline$\overline{\text { Control }}$ & 9.33 & 1.79 & 8.80 & 8.32 & 1.51 & 5.73 \\
\hline MLE & 38.96 & 6.81 & 35.77 & 39.83 & 8.66 & 30.15 \\
\hline $\mathbf{A E}$ & 29.88 & 4.54 & 24.60 & 28.59 & 5.35 & 21.10 \\
\hline YE & 22.71 & 3.21 & 19.80 & 20.77 & 3.45 & 16.68 \\
\hline CPFE & 18.82 & 2.56 & 15.41 & 16.36 & 2.76 & 11.70 \\
\hline Mean & 23.94 & 3.78 & 20.87 & 22.77 & 4.34 & 17.07 \\
\hline LSD $0.05 \%$ & 1.23 & 0.84 & 1.32 & 1.05 & 0.25 & 0.98 \\
\hline
\end{tabular}

See footnote of table (6)

Table 9. Effect of organic extracts on micronutrient uptake $\left(\mathrm{mg} \mathrm{plant}^{-1}\right)$ of wheat plants grown in sandy soil

\begin{tabular}{lcccccccc}
\hline Treatment & \multicolumn{4}{c}{ Straw } & \multicolumn{5}{c}{ Grains } \\
\cline { 2 - 9 } & Fe & Zn & Mn & Cu & Fe & Zn & Mn & Cu \\
\hline Control & 97.99 & 40.06 & 79.36 & 5.44 & 78.14 & 31.91 & 63.50 & 4.87 \\
MLE & 292 & 129 & 232 & 32.71 & 287 & 132 & 235 & 33.86 \\
AE & 205 & 94.69 & 172 & 22.08 & 197 & 89.77 & 162 & 21.30 \\
YE & 162 & 74.81 & 142 & 15.66 & 147 & 70.92 & 127 & 14.82 \\
CPFE & 131 & 59.61 & 107 & 11.35 & 112 & 52.69 & 93.17 & 11.13 \\
Mean & 178 & 79.67 & 147 & 17.45 & 164 & 75.43 & 136.13 & 17.20 \\
LSD 0.05\% & 2.92 & 3.26 & 4.65 & 1.42 & 3.40 & 2.71 & 2.53 & 1.02 \\
\hline SEe 0000
\end{tabular}

See footnote of table (6)

Significant increases in $\mathrm{Fe}, \mathrm{Zn}$ and $\mathrm{Mn}$ uptake occurred upon spraying with extracts. Highest percentage increases valued 197, 109, 65 and $43 \%$ were caused by MLE, AE, YE, CPFE, respectively in straw. Fe-uptake; 222, 136,86 and $48 \%$, respectively for $\mathrm{Zn}$-uptake and $192,116,78$ and $34 \%$, respectively of straw Mnuptake. Important plant hormones like Auxins, Gibberellins and Cytokinin existing in the extracts induce cell division and increase cell enlargement and lead to balance physiological (Merwad, 2017; Desoky et al., 2018.)

Organic extracts have been used in agriculture and horticulture as bio stimulants to promote plant growth and increase crop yields (Veerappan et al., 2019)

\section{Conclusion}

The results of this study indicate that foliar spray on wheat with extracts of Moringa leaves extract (MLE); Alge extract (AE); Yeast extract (YE) and Cabbage pollen flowers extract (CPFE) had beneficial effects on plant growth, yield, macro and micro nutrient uptake. Increases were the highest with MLE in all parameters, straw and grains yield, biological yield, protein content, NPK, Fe, $\mathrm{Zn}, \mathrm{Cu}$ and Mnuptake of wheat plants. 


\section{REFERENCES}

Abdalla, M.A. (2013). The potential of moringa oleifera extract as a biostimulant in enhancing the growth, biochemical and hormonal contents in rocket (Eruca versicaria subsp. Sativa) plants. Int. J. Plant Physiol. Bioch., 5 (3): 42-49.

Abd El-Mageed, T.A., W.M. Semida and M.M. Rady (2017). Moringa leaf extract as biostimulant improves water use efficiency, physio-biochemical attributes of squash plants under deficit irrigation. Agric. Water Manag, 193 : 46-54.

Abdel-Fattah, M.K. and A.M.A. Merwad (2016). Approach for reclamation and improving fertility of saline-sodic soils. Egypt. J. Soil Sci., 56 (4): 573-588.

Abdel-Rahman, S.S.A. and A.A.S. Abdel-Kader (2019). Response of Fennel (Foeniculum vulgare, Mill) plants to foliar application of moringa leaf extract and benzyladenine (BA). S. Afr. J. Bot. (in press).

Abou-Aly, H.A. (2005). Stimulatory effect of some yeast application on response of tomato plants to inoculation with biofertilizeres. Ann. Sci., Moshtohor, 43 (2): 595-609.

Abou El-Magd, M.M., M.F. Zaki and S.A. Abo Sedera (2018). Bio-fertilization and foliar application of Milagro bio-stimulant in relation to growth, head yield and quality as well as mineral $\mathrm{K}$ requirements of Chinese cabbage. Mid. East J. Agric. Res., 7 (4): 1310 $-1322$.

Abusuwar, A.O. and R.A. Abohassan (2017). Effect of Moringa olifera leaf extract on growth and productivity of three cereal forages. J. Agric. Sci., 9 (7): 236-243.

Amer, S.S.A. (2004). Growth, green pods yield and seeds yield of common bean (Phaseolus vulgaris $\mathrm{L}$ ) as affected by active dry yeast, salicylic acid and their interaction. J. Agric. Sci., Mansoura Univ., 29 (3): 1407-1422

Bates, L.S., R.P. Waldeen and I.D. Teare (1973). Rapid determination of free proline for water stress studies. Plant and Soil, 39: 205-07.
Bishni, U.R. and I.L. Hughes (1979). Agronomic performance and protein content of fallplanted tritica, wheat and rye. Agron. J., 71 : 359-360.

Black, C.A., D.D. Evans, J.L. White, L.E. Ensminger and F.E. Chark (1965). Methods of Soil Analysis". Part. Z. Agron. Ame. Soc. Agron. Inc. Modison Wisc.

Bulgari, R., G. Franzoni and A Ferrant (2019). Bio stimulants application in horticultural crops under abiotic stress conditions. Agron., 9 (306): 1-30.

Chapman, D.H. and P.F. Pratt (1961). Methods of Analysis for Soil, Plant and Waters. Calif. Univ., Div. Agric. Sci.

Desoky, E.M., A.M. Merwad and A.S. Elrys (2017). Response of pea plants to natural biostimulants under soil salinity stress. Ame. J. Plant Physiol., 12: 28-37.

Desoky, E.M., A.M. Merwad and M.M. Rady (2018). Natural biostimulants improve saline soil characteristics and salt stressed-sorghum performance. Commun. Soil Sci. and Plant Anal., 49 (8): 967-983.

Draz, I.S., A.A. Elkhwaga, A.A. Elzaawely, H.M. El-Zahaby and A.A. Ismail (2019). Application of plant extracts as inducers to challenge leaf rust of wheat. Egypt. J. Biol. Pest Control., 29 (6):1-6.

Elrys, A.S. and A.M.A. Merwad (2017). Effect of alternative spraying with silicate and licorice root extract on yield and nutrients uptake by pea plants. Egypt. J. Agron., 39 (3): $279-292$.

Fadeels, A.A. (1962). Location and properties of chloroplasts and pigment determination in shoots. J. Plant Phys., 15:130-47.

FAO (2011). The state of food and agriculture. Women in aagriculture. Closing the Gender gap for Dev.

Fuglie, L. (2000). The miracle tree: Moringa oleifera: Natural nutrition for the tropics. The multiple Attributes of Moringa, 172

Hammad, S.A.R. and O.A.M. Ali (2014). Physiological and biochemical studies on drought tolerance of wheat plants by 
application of amino acids and yeast extract. Ann. Agric. Sci., 59 (1): 133-145

Jackson, M.L. (1973). Soil Chemical Analysis. Prentice Hall, Ic., Englewood Califfs, New Jersy, USA.

Khan, W., U.P. Rayirath, S. Subramanian, M.N. Jithesh, P. Rayorath, D.M. Hodges, A.T.J.S. Critchley-Craigie and J. Norrie (2009). Seaweed extracts as bio stimulants of plant growth and development. J. Plant Growth Regul., 28:386-399

Kulkarni, M.G., K.R.R. Rengasamy, S.C. Pendota, J. Gruz, L. Pla cková, O. Novák, K. Doležal and J. Van Staden (2019). Bioactive molecules derived from smoke and seaweed Ecklonia maxima showing phytohormonelike activity in Spinacia oleracea L. New Biotech., 48: 83-89.

Mady, M.A. (2009). Effect of foliar application with yeast extract and zinc on fruit setting and yield of faba bean (Vicia faba L.). J. Biol. Chem. Environ. Sci., 4 (2): 109-127.

Makkar, H.P.S. and K. Becker (1996). Nutritional value and antinutritional components of whole and ethanol extracted of Moringa oleifera leaves. Anim. Feed Sci. Techn., 63 : 211-228.

Martin, L.P. (2008). The Moringa Tree. Echo Technical note. http://www.echonet.org. Retrieved 17/06/2008

Merwad, A.M.A. (2015). Effect of Moringa oleifera extracts on the growth, yield and nutrient uptake of spinach (Spinacia oleracea L.). Greener J. Soil Sci. Plant Nutr., 2 (1): 16-22.

Merwad, A.M. (2017). Effect of humic and fulvic substances and moringa leaf extract on Sudan grass plants grown under saline conditions. Canadian J. Soil Sci., 97 (4): $703-$ 716. DOI: 10.1139/CJSS-2017-0050.

Merwad, A.M. (2018). Using Moringa oleifera extract as biostimulant enhancing the growth, yield and nutrients accumulation of pea plants. J. Plant Nutr., 41 (4): 425-431.

Merwad, A.M.A. (2019). Using humic substances and foliar spray with Moringa leaf extract to alleviate salinity stress on wheat. In: The
Handbook of Environ. Chem. Sustainability of Agric. Environ. Egypt: Part II- SoilWater-Plant Nexus, 77: 265-286. Hdb Env Chem, Springer, Berlin, Heidelberg. https:// doi.org/10.1007/698_2018-298.

Merwad, A.M.A. and M.K. Abdel-Fattah (2017). Improving productivity and nutrients uptake of wheat plants using Moringa oleifera leaf extract in sandy soil. J. Plant Nutr., 40 (10): 1397- 1403.

Mohamed, M.F., A.T. Thalooth, R.E.Y. Essa and M.E. Gobarah (2018). The stimulatory effects of tryptophan and yeast on yield and nutrient status of wheat plants (Triticum aestivum) grown in newly reclaimed soil. Mid. East J. Agric. Res., 7 (1): 27-33.

Mohamed, Y.A.E., E.A. El-Ghamriny, A. Bardisi and D.A.S. Nawar (2019) .Growth and productivity of garlic crop under different fertilizers type and some extracts. Life Sci. J., 16 (3): 79-89.

Mohsen, A.A.M., A.S.A. Salama and F.M.A. El-Saadony (2016). The effect of foliar spray with cyanobacterial extracts on growth, yield and quality of lettuce plants (Lactuca sativa L.). Mid. East J. Agric., 5 (1): 90- 96.

Morsi, M.K., B. El-Magoli, N.T. Saleh, E.M. ElHadidy and H.A. Barakat (2008). Study of antioxidants and anticancer activity licorice Glycyrrhiza glabra extracts. Egypt. J. Nutr. and Feeds, 2 (33): 177-203

Moyo, B., P.J. Masika, A. Hugo and V. Muchenje (2011). Nutritional characterization of Moringa (Moringa oleifera Lam) leaves. Afr. J. Biotec., 10 (60):12925 - 12933.

Parađiković, N., T. Teklić, S. Zeljković, M. Lisjak and M. Špoljarević (2019). Biostimulants research in some horticultural plant species-A review. Food Energy Secur., 8 (2): 1-17.

Phiri, C. and D.N. Mbewe (2010). Influence of Moringa oleifera leaf extracts on germination and seedling survival of three common legumes. Int. J. Agric. Biol., 12: 315 - 317.

Piper, C.S. (1950). Soil and plant anaylsis. Interscince Publishers Inc. New York, USA. 
Prabhu, M.A., A. Ramesh and K. Rajamani (2009). Influence of biostimulants on growth, yield and economics of Kalmegh (Andrographis paniculata). Madras Agric. J., 96 (1-6): 150 $-155$.

Selvam, G.G and K. Sivakumar (2014). Influence of seaweed extract as an organic fertilizer on the growth and yield of Arachis hypogea $L$. and their elemental composition using SEM-Energy Dispersive Spectroscopic analysis. Asian Pacific J. Repr., 3 (1): 18-22.

Sharma, S.H.S., G. Lyons, C. McRoberts, D. McCall, E. Carmichael, F. Andrews, R. Swan, R. McCormack and R. Mellon (2015). Bio-stimulant activity of brown seaweed species from Strangford Lough: compositional analyses of polysaccharides and bioassay of extracts using mung bean (Vigno mungo L.) and pak choi (Brassica rapa chinensis L.). J. Appl. Phycol., 24 : 1081-1091.

Sharpley, A.N. (1985). Phosphorus cycling in unfertilized and agricultural soils. Soil Sci. Soci. Ame. J., 49: 905-911.

Thanaa, S.M., N.E. Kassim, A. Rayya and A.M. Abdalla (2017). Influence of foliar application with moringa (Moringa oleifera L.) leaf extract on yield and fruit quality of hollywood plum cultivar. J. Hort., 4:193.

Toscano, S., D. Romano, D. Massa, R. Bulgari, G. Franzoni and A. Ferrante (2019). Bio-stimulant applications in low input horticultural cultivation systems. Italus Hortus., 25: 27-36.

Ullah, A., S. Ali and S.M. Shah (2019). Influence of foliar application of biostimulants on growth, yield and chemical composition of tomato. Int. J. Biosci., 14: 309-316.

Veerappan, V., U. Rangnathan and J. Mannar (2019). Effect of organic foliar spray with pulse sprout extract on seed yield and quality of rice (Oryza sativa). J. Plant Nutr., 42 (8): 900-914,

Wanas, A.L. (2002). Resonance of faba bean (Vicia faba L.) plants to seed soaking application with natural yeast and carrot extracts. Ann. Agric. Sci. Moshtohor, 40 (1): 259-278.

Watanabe, F.S. and S.R. Olsen (1965). Test of ascorbic acid method for determing phosphorus in water and $\mathrm{NaHCO}_{3}$ extracts from soil. Soil Sci. Soc. Am. Proc., 29 : 677 -678 .

Wettestein, D. (1957). Chlorophyll-Lethal undder submink roskopische formivechoel der plastiden. Exp. Cell Res., 12: 427-33.

Zhang, X. and E.H. Ervin (2004). Cytokinincontaining seaweed and humic acid extracts associated with creeping bentgrass leaf cytokinins and drought resistance. Crop Sci., 44: 1737-1745. 


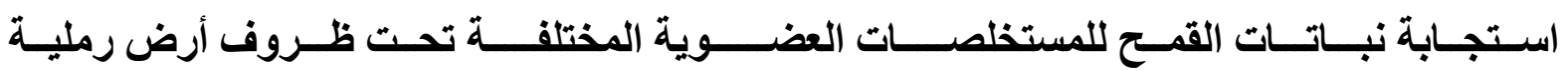

$$
\text { أميرة محمد صبرى - إبرا هيم رمضان محمد ـ عطيات السيد نصر الله ـ عبد الرحمن محمد أمين مرواد }
$$

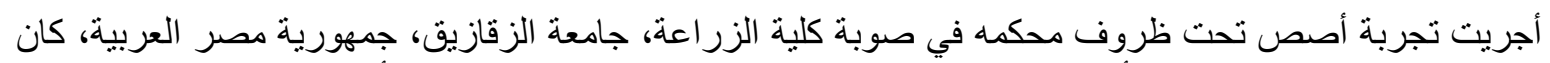

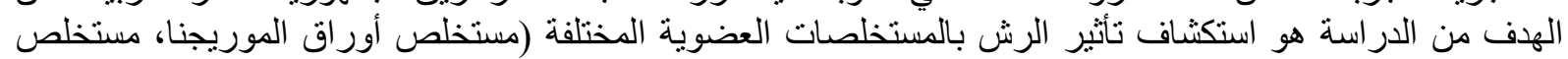

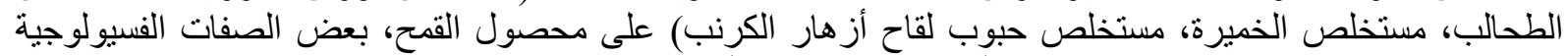

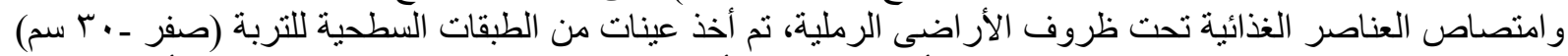

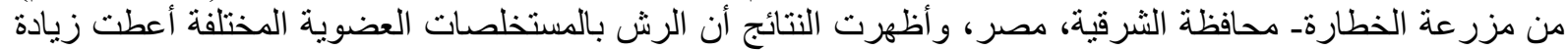

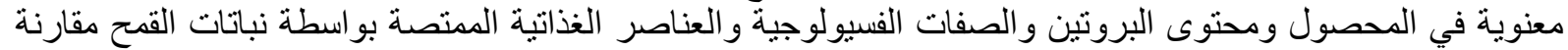

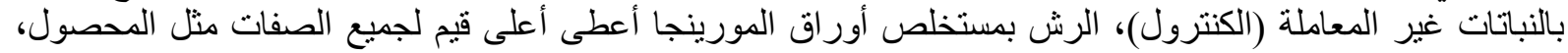

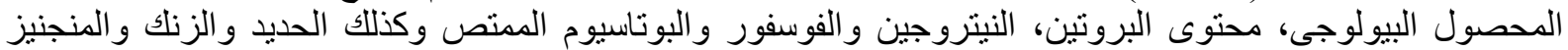

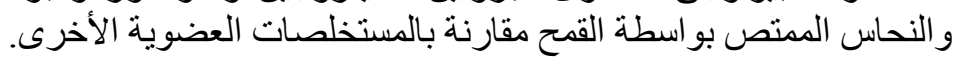

أستاذ الأر اضي - كلية الزر اعة بمشتهر - جامعة بنها.

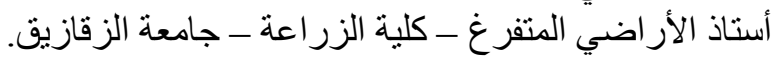

